\title{
The Relationship Between Impact of Pregnancy Complaints on The Life Quality of The Pregnant Women and Their Psychosocial Health Level
}

\author{
Gebelikteki Yakınmaların Yaşam Kalitesine Etkisi ile Psikososyal Sağlık Düzeyi \\ Arasındaki İlişkinin İncelenmesi
}

Yeşim Aksoy Derya ${ }^{*}{ }^{1}$, Zeliha Özşahin ${ }^{1}$, Tuba Uçar ${ }^{l}$,Çiğdem Erdemoğlu ${ }^{l}$, Hacer Ünver ${ }^{l}$

\begin{abstract}
Aim: This study seeks to identify the relationship between the impact of pregnancy complaints on the quality of life of the pregnant women and their psychosocial health level. Methods: This study which was designed as a descriptive was conducted on 383 pregnant women who applied to in the Pregnancy Clinic of a public hospital, between March- September 2017.The data was obtained through "Personal Information Form", "Assessment Scale for Pregnancy Complaints and Their Impact on Life Quality" (ASPCILQ) and "Assessment Scale for Psychosocial Health During Pregnancy" (ASPHDP). Statistical evaluation included numbers, percentages, mean values, standard deviation, Pearson correlation, independent samples T Test and One Way Anova analysis. Results: The mean age of the pregnant women was $28,3 \pm 5,4,27,4 \%$ graduated high school and $66,6 \%$ reported that their income was equal to their expenditures. The total mean score of the women on ASPCILQ was $74,1 \pm 27,5$, while it was $4,0 \pm 0,4$ ' on ASPHDP. As for the mean scores of the sub-dimensions, it was 4,3 $\pm 0,4$ on the sub-dimension of "Pregnancy and Relation with Spouse"; $3,2 \pm 0,7$ on the sub-dimension of "Anxiety and Stress"; $4,6 \pm 0,5$ on the sub-dimension of "Domestic Violence", 3,9 $\pm 0,5$ on the sub-dimension of "The Need for Psychosocial Support", 4,4 $\pm 0,4$ on the subdimension of "Family Profile" and 3,8 $\pm 0,7$ on the sub-dimension of "Physical- Psychosocial Changes Attributable to Pregnancy". A significant negative correlation was found between ASPCILQ and ASPHDP, and the sub-dimensions of "Anxiety and Stress", "The Need for Psychosocial Support" and "Physical- Psychosocial Changes Attributable to Pregnancy". It was reported that the increase in negative impact of pregnancy complaints on the life quality of the pregnant women causes a decrease in their psychosocial health $(p<0,05)$. Conclusion: The findings of the study revealed a reverse relationship between the impact of pregnancy complaints on the life quality and the psychosocial health of pregnant women. It also highlighted the fact that while the negative impact of pregnancy complaints on the life quality increases, the psychosocial health level of pregnant women deteriorates.
\end{abstract}

Key words: Pregnancy, pregnancy complaints, quality of life, psychosocial health level

\section{ÖZET}

Amaç: $\mathrm{Bu}$ araştırmada, gebelikteki yakınmaların yaşam kalitesine etkisi ile psikososyal sağlık düzeyi arasındaki ilişkinin belirlenmesi amaçlanmıştır. Yöntem: İlişkisel tanımlayıcı nitelikte planlanan bu araştırma, Mart-Eylül 2017 tarihleri arasında, bir kamu hastanesinin gebe polikliniğine başvuran 383 gebe üzerinde yürütülmüştür. Veriler, "Kişisel Tanıtım Formu", "Gebelikte Yakınmalar ve Yaşam Kalitesine Etkisi Ölçeği (GYYKEÖ)" ve "Gebelikte Psiko-Sosyal Sağlığı Değerlendirme Ölçeği (GPSDÖ)" aracıllı̆ı ile elde edilmiştir. İstatistiksel değerlendirmede; sayı, yüzde, ortalama, standart sapma, pearson korelasyon, bağımsız gruplarda t testi ve anova analizi kullanılmıştır. Bulgular: Yaş ortalaması 28,3 $\pm 5,4$ olan gebelerin \%27,4'ü lise mezunu olup, $\% 66,6$ 'sı gelirinin giderine eşit olduğunu belirtmiştir. Araştırmada, GYYKEÖ toplam puan ortalaması 74,1 $\pm 27,5$, GPSDÖ toplam puan ortalamasi

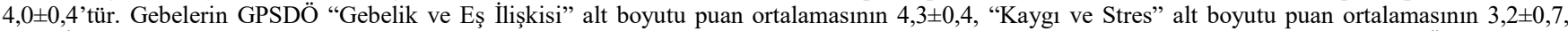

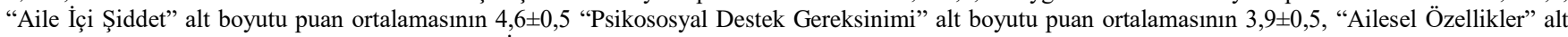

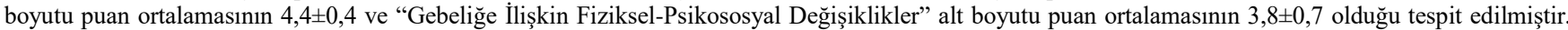
GYYKEÖ ile GPSDÖ toplam ve "Kaygı ve Stres", "Psikososyal Destek Gereksinimi” ile "Gebeliğe İlişkin Fiziksel-Psikososyal Değişiklikler" alt boyutları arasında negatif yönde anlamlı bir ilişki olduğu ve gebelikteki yakınmaların yaşam kalitesine olumsuz etkisi arttıkça gebelikte psikososyal sağlık düzeyinin azaldığı tespit edilmiştir $(p<0,05)$. Sonuç: Gebelikteki yakınmaların, yaşam kalitesi ile psikososyal sağlık düzeyi arasında ters bir ilişki olduğu, gebelikteki yakınmaların yaşam kalitesine olan olumsuz etkisi arttıkça, gebelerdeki psikososyal sağlık düzeyinin de anlamlı düzeyde azaldığı belirlenmiştir.

Anahtar Kelimeler: Gebelik, gebelik yakınmaları, yaşam kalitesi, psikososyal sağlık düzeyi

Received / Geliş tarihi: 20.03.2018, Accepted / Kabul tarihi: 08.05.2018

${ }^{1}$ Department of Midwifery, Faculty of Health Sciences Inonu University, Malatya / Turkey.

*Address for Correspondence / Yazışma Adresi: Yeşim AKSOY DERYA. Department of Midwifery, Faculty of Health Sciences Inonu University, Malatya-TÜRKIYE, E-mail: yesim.aksoy@inonu.edu.tr

Derya YA, Özşahin Z, Uçar T, Erdemoğlu Ç, Ünver H. Gebelikteki Yakınmaların Yaşam Kalitesine Etkisi ile Psikososyal Sağlık Düzeyi Arasındaki İlişkinin İncelenmesi. TJFMPC, 2018;12 (3): 171-177. DOI: 10.21763/tjfmpc.452447 


\section{GíRIŞ}

Gebelik sürecinde, fetal büyüme ve gelişmeyi sağlamak, anneyi doğuma hazırlamak, gebelik ve doğum sırasında anne ve fetüsün bazı risklerden korunmasını sağlamak amacıyla, anne vücudunda fizyolojik, psikolojik ve biyokimyasal bir takım değişiklikler yaşanmaktadır. ${ }^{1-5}$ Gebeliğe özgü fizyolojik değişiklikler, psikolojik değişikliklerin kaynağını oluştururken, bu değişimler ile birlikte ortaya çıkan yakınmalar gebenin yaşam kalitesini ve psikososyal sağlığını olumsuz yönde etkileyebilmektedir. ${ }^{2,46-9}$ Yapılan çalışmalarda, gebelikle ilişkili fiziksel semptomlar, yorgunluk, duygusal değişimler ve yaşanan sınırlılıkların yaşam kalitesinin birçok alanında azalmaya neden olduğu ifade edilmiştir. ${ }^{7,10,11}$ Normal seyreden gebeliklerde bile belirtilen fiziksel ve ruhsal değişikliklerin, kadınların günlük işlerini yapabilme yetisini azaltabileceği bildirilmiştir. $^{6}$ Gebe kadınların yakınmalara bağlı aldıkları hastalık izinlerinin, 20 ile 39 yaşları aralığında çalışan tüm kadınların ve 32. gebelik haftasına kadar alınan tüm izinlerin üçte birini oluşturması, yakınmaların ciddiyetini ve yaşam kalitesine olan etkisini göstermektedir. ${ }^{8}$

Literatürde, gebelik sürecinde meydana gelen bedendeki fizyolojik değişikliklerin, doğumla ilgili anksiyete ve duygu durum değişikliğine etki yarattığı bildirilmiştir. ${ }^{12}$ Ayrıca gebe kadının yaşadığ1 fiziksel, psikolojik, sosyal ve kişisel stres etkenleri ile etkili bir şekilde baş edememesi gibi bir durumda gebelik, doğum ve ebeveyn olma gibi olaylar anne için gelişimsel ve durumsal bir krize dönüşebilir. ${ }^{12,13}$ Gebelikte ruh sağlığının iyi olması, anne ve fetus sağlığı için önemlidir. ${ }^{14}$ Yüzyıllardır gebelik, kadın hayatında bir ruhsal iyilik hali ve mutluluk dönemi olarak bilinirken, günümüzde bu görüş artık kabul edilmemektedir. ${ }^{5} \mathrm{Bu}$ nedenle, gebelik döneminde gebeye en yakın olan kişiler olan birinci basamak sağllk personelinin gebelerin fizyolojik gereksinimlerin yanı sıra, psikososyal gereksinimlerini de göz önünde bulundurmaları ve gebeliğe psikolojik uyumu kolaylaştırmaları tavsiye edilmektedir. ${ }^{1,14,15} \mathrm{Bu}$ bağlamdan yola çıkarak bu çalışmada, gebelikte yaşanan yakınmaların yaşam kalitesine etkisi ve bu etkinin psikososyal sağlık düzeyi ile olan ilişkisini değerlendirmek amaçlanmıştır.

\section{GEREÇ VE YÖNTEM}

İlişkisel tanımlayıcı nitelikte tasarlanan bu araştırma, gebelikteki yakınmaların yaşam kalitesine etkisi ile psikososyal sağlık düzeyi arasındaki ilişkinin incelenmesi amacıyla yapılmıştır. Araştırmanın evrenini, Mart-Eylül 2017 tarihleri arasında, Malatya ilindeki bir kamu hastanesinin kadın hastalıkları ve doğum polikliniklerine başvuran gebeler oluşturmuştur. Power analizi kullanılarak yapılan hesaplamada araştırmanın örneklemi; 0,05 yanılgı düzeyi, \%95 güven aralığı ve \%80 evreni temsil etme yeteneği ile en az 383 gebe olarak belirlenmiştir. Belirlenen örneklem grubuna ulaşılana kadar, ilgili hastanede kadın hastalıkları ve doğum polikliniklerine başvuran ve araştırmaya alınma kriterlerini sağlayan kadınlar olasılıksız rastlantısal örnekleme yöntemi ile seçilmiştir. Araştırmaya; sözel iletişim kurulabilen ve gebeliği yardımcı üreme teknikleri kullanılarak gerçekleşmemiş olan sağlıklı gebeler dahil edilmiştir. Veriler, ilgili kamu hastanesinin kadın hastalıkları ve doğum polikliniklerine izlem için başvuran gebelerle yapılan yüz, yüze görüşme yöntemi kullanılarak elde edilmişstir.

\section{Veri Toplama Araçları}

Verilerin elde edilmesinde, "Kişisel Tanıtım Formu", "Gebelikte Yakınmalar ve Yaşam Kalitesine Etkisi Ölçeği" ve "Gebelikte PsikoSosyal Sağllğı Değerlendirme Ölçeği”, kullanılmıştır.

\section{Kişisel Tanıtım Formu}

Gebe kadınların tanıtıcı özelliklerini (yaş, eğitim durumu, ekonomik durum, aile tipi, çalışma durumu, gravida, yaşayan çocuk sayısı, gebelik haftasi) belirlemek amacıyla araştırmacılar tarafindan oluşturulmuştur.

\section{Gebelikte Yakınmalar ve Yaşam Kalitesine Etkisi Ölçeği (GYYKEÖ)}

Gebelikte yakınmalar ve yaşam kalitesine etkisini ölçen bir ölçektir. Ölçeğin geçerlik güvenirliği, 2016 yılında Özorhan EY. tarafından yapılmıştır. Ölçekte, 42 madde bulunmakta ve iki bölümden oluşmaktadır. Birinci bölümde, gebelikte ortaya çıkan yakınmalardan son bir ay içerisinde ne kadar sıklıkla karşılaşıldığı değerlendirilmekte olup, bu

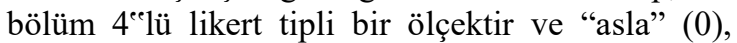
"nadiren" (1), "bazen" (2), "sik sik" (3) olarak kodlanmaktadır. Eğer birinci bölümden her bir yakınma için 1-3 arasında bir işaretleme yapılırsa, ölçeğin ikinci bölümüne geçilmektedir. İkinci bölüm de, yakınmaların günlük yaşam aktivitesini

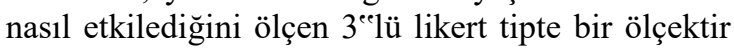
ve "hiç sınırlamamakta (0)", "az sınırlamakta (1)", çok sinırlamakta (2) " şeklinde işaretleme yapılmaktadır. Ölçeğin kesme noktası bulunmamaktadır. Toplam puan yükseldikçe, yaşam kalitesi düşmektedir. Ölçeğin cronbach alfa güvenirlik katsayısı 0,91 'dir. ${ }^{11} \mathrm{Bu}$ araştırmada, cronbach alfa güvenirlik katsayısının 0.86 olduğu tespit edilmiştir. 


\section{Gebelikte Psiko-Sosyal Să̆lı̆̆ Değerlendirme Ölçĕgi (GPSDÖ)}

Gebelikte psiko-sosyal sağlığı değerlendirmek amacıyla, Yıldız tarafından geliştirilmiş olan ölçek 46 maddeliktir. Gebelikte Psiko-Sosyal Sağlığ Değerlendirme Ölçeği 5'li likert tipi bir ölçektir. Ölçekteki her bir madde 1'den 5'e kadar puanlanmaktadır. Ölçekte 6 alt boyut bulunmaktadır. Ölçekteki birinci alt boyutta yer alan 13 madde "Gebelik ve eş ilişkisine ait özellikler"i, ikinci alt boyutta yer alan 8 madde "Kayg1 ve strese ait özellikler"i, üçüncü alt boyutta yer alan 7 madde "Aile içi şiddete ait özellikler"i, dördüncü alt boyutta yer alan 7 madde "Psikososyal destek gereksinimine ait özellikler"i beşinci alt boyutta yer alan 4 madde "Ailesel özellikler"i ve altınc1 alt boyutta yer alan 6 madde de "Gebeliğe ilişkin fiziksel-psiko-sosyal değişikliklere ait özellikler"i kapsamaktadır. Ölçeğin değerlendirilmesinde elde edilen toplam puan, madde sayısına bölünerek madde puan ortalaması saptanır ve 1 ile 5 arasında sonuç elde edilir. Sonuçta, toplam puan 5'den uzaklaşıp 1'e yaklaştıkça gebelikte psiko-sosyal sağlıkta o düzeyde problem olduğunu gösterir ve 1 puan psiko-sosyal sağlığın çok kötü olduğunu ifade eder. Alt boyutlarda da aynı değerlendirme söz konusudur ve puan 1'e yaklaştığı ölçüde o alt boyuta ait problem olduğunu gösterir. Ölçekten elde edilebilecek minimum değer 1 ve maksimum değer 5 tir. Ölçeğin kesme noktas1 bulunmamaktadır. Ölçeğin cronbach alfa güvenirlik katsayısı 0,93 'dür. ${ }^{14} \mathrm{Bu}$ araştırmada, cronbach alfa güvenirlik katsayısının 0,71 olduğu tespit edilmiştir.

Tablo 2'de, katılımcıların GYYKEÖ ile GPSDÖ'den aldıkları puan ortalamalarının dağılımı verilmektedir. Katılımcıların GYYKEÖ aldıkları toplam puan ortalamasının 74,1 $\pm 2,7$, GPSDÖ aldıkları toplam puan ortalamasının $4 \pm 0,3$ olduğu belirlenmiştir. GYYKEÖ alt boyutlarından alınan toplam puan ortalamaları ise siras1 ile; " $4,2 \pm 0,4$ (Gebelik ve Eş İlişkisi)", " $3,2 \pm 0,7$ (Kaygı ve

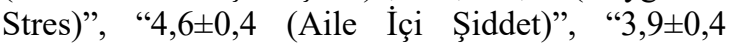
(Psikososyal Destek Gereksinimi)" " $4,4 \pm 0,4$

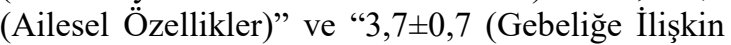
Fiziksel-Psikososyal Değişiklikler)” şeklindedir. Katılımcıların tanıtıcı özellikleri ile GYYKEÖ ve GPSDÖ toplam puan ortalamalarının karşılaştırılması Tablo 3' de verilmiştir. Yaş grupları, aile tipi, gravida, gebeliğin planlı olması, yaşayan çocuk sayısı ile GYYKEÖ ve GPSDÖ toplam puanları arasında istatistiksel açıdan anlamlı bir fark olmadığı saptanmıştır $(\mathrm{p}>0.05)$. Buna karşın algılanan ekonomik durum, çalışma durumu

\section{Verilerin Değerlendirilmesi}

Verilerin kodlanması ve değerlendirilmesi, SPSS 16.0 paket programını kullanılarak bilgisayar ortamında gerçekleştirilmiştir. İstatistiksel değerlendirmede; yüzdelik dağılım, aritmetik ortalama, standart sapma, cronbach alfa ve pearson korelasyon analizi kullanılmıştır. İstatistiksel anlamlılık düzeyi $\mathrm{p}<0.05$ kabul edilmiştir.

\section{Etik Düzenlemeler}

Araştırmanın uygulandığı kurumdan yazılı izin ve İnönü Üniversitesi Sağlık Bilimleri Girişimsel Olmayan Klinik Araştırmalar Etik Kurulu'ndan onay (Karar No: 2017 / 7-4) alınmıştır. Ayrıca, araştırmaya başlamadan önce katılımcılar araştırma hakkında bilgilendirilmiş ve gönüllü olanlar araştırmaya dahil edilmiştir.

\section{BULGULAR}

Katılımcıların tanıtıcı özelliklerinin dağılımı Tablo 1'de verilmiştir. Araştırmaya katılan gebelerin yaş ortalaması $28,3 \pm 5,4$ olup, $\% 86,7$ ' sinin 18-34 yaş grubunda olduğu saptanmıştır. Gebelerin \%27,4'ünün lise mezunu olduğu, \%79,1 inin çalışmadığ $\breve{1}_{1}$ ve \%66,6'sının gelirinin giderine eşit olduğu belirlenmiştir. Araştırmaya katılan gebelerin \%32,9'unun primigravida olduğu, \%39,4'ünün yaşayan çocuğunun olmadığı ve $\% 67,1$ 'nin 3.trimesterde olduğu saptanmıştır.

ve gebeliğin bulunduğu trimester ile GYYKEÖ toplam puan ortalaması arasında ve eğitim durumu ile GPSDÖ toplam puan ortalaması arasında istatistiksel açıdan anlamlı bir fark olduğu saptanmıştır $(\mathrm{p}<0.05)$.

Katılımcıların GYYKEÖ ile GPSDÖ puan ortalamaları arasındaki ilişki Tablo 4' te verilmiştir. GYYKEÖ ile GPSDÖ '"gebelik ve eş ilişkileri”, "'aile içi şiddet', “'ailesel özellikler', alt boyutları toplam puan ortalamaları arasında istatistiksel açıdan anlamlı bir ilişki olmadığı saptanmıştır ( $>00,05)$. GYYKEÖ ile GPSDÖ "Kayg1 ve Stres", "Psikososyal Destek Gereksinimi” ve "Gebeliğe İlişkin Fiziksel-Psikososyal Değişiklikler" alt boyutları ile "GPSDÖ Toplam" puan ortalamaları arasında negatif yönde önemli bir ilişki olduğu ve gebelikteki yakınmaların yaşam kalitesine olumsuz etkisi arttıkça, gebelikte psikososyal sağlık düzeyinin azaldığı belirlenmiştir $(\mathrm{p}<0.05)$. 


\begin{tabular}{|c|c|c|}
\hline Değişken & \multicolumn{2}{|c|}{ Mean \pm SS } \\
\hline Yaş (yıl) & \multicolumn{2}{|c|}{$28.3 \pm 5.4$} \\
\hline Yas grubu & $\mathbf{n}$ & $\%$ \\
\hline $18-34(\mathrm{y} 1 \mathrm{l})$ & 332 & 86,7 \\
\hline$\geq 35(\mathrm{y} 11)$ & 51 & 13,3 \\
\hline \multicolumn{3}{|l|}{ Algılanan Ekonomik durum } \\
\hline Gelirim Giderimden Az & 36 & 9,4 \\
\hline Gelirim giderime eşit & 255 & 66,6 \\
\hline Gelirim giderimden yüksek & 92 & 24 \\
\hline \multicolumn{3}{|l|}{ Aile tipi } \\
\hline Çekirdek & 308 & 80,5 \\
\hline Geleneksel & 71 & 18,5 \\
\hline Parçalanmış & 4 & 1 \\
\hline \multicolumn{3}{|l|}{ Ĕ̆itim } \\
\hline Okur-yazar değil & 14 & 3,7 \\
\hline Okur-yazar & 7 & 1,8 \\
\hline İlkokul & 100 & 26,1 \\
\hline Ortaokul & 59 & 15,4 \\
\hline Lise & 105 & 27,4 \\
\hline Üniversite ve üstü & 98 & 25,6 \\
\hline \multicolumn{3}{|l|}{ Calıșma Durumu } \\
\hline Calışmıyor & 303 & 79,1 \\
\hline Çalışıyor & 80 & 20,9 \\
\hline \multicolumn{3}{|l|}{ Gravida } \\
\hline Primigravida & 126 & 32,9 \\
\hline Multigravida & 257 & 60,1 \\
\hline \multicolumn{3}{|l|}{ Gebeliğin planlı olması } \\
\hline Evet & 315 & $\% 82,2$ \\
\hline Hayır & 68 & $\% 17,8$ \\
\hline \multicolumn{3}{|l|}{ Yaşayan çocuk } \\
\hline Yok & 151 & 39,4 \\
\hline Var & 232 & 60,6 \\
\hline \multicolumn{3}{|l|}{ Trimester } \\
\hline 1 & 52 & 13,6 \\
\hline 2 & 74 & 19,3 \\
\hline 3 & 257 & 67,1 \\
\hline Toplam & 383 & 100.0 \\
\hline
\end{tabular}

Tablo 2. Katılımcıların GYYKEÖ ile GPSDÖ aldıkları puan ortalamalarının dağılımı

\begin{tabular}{|l|c|c|c|}
\hline Ölçekler & Alınabilecek Min-Maks & Alınan Min-Maks & Mean \pm SS \\
\hline GYYKEÖ & $0-210$ & $0-170$ & $74,1 \pm 2,7$ \\
\hline GPSDÖ & & & \\
\hline Gebelik ve Eş İlişkisi & $1.00-5.00$ & $3.00-5.00$ & $4,2 \pm 0,4$ \\
\hline Kayg1 ve Stres & $1.00-5.00$ & $1.00-5.00$ & $3,2 \pm 0,7$ \\
\hline Aile içi şiddet & $1.00-5.00$ & $1.88-5.00$ & $4,6 \pm 0,4$ \\
\hline Psikososyal destek gereksinimi & $1.00-5.00$ & $2.14-5.00$ & $3,9 \pm 0,4$ \\
\hline Ailesel özellikler fiziksel- & $1.00-5.00$ & $3.00-5.00$ & $4,4 \pm 0,4$ \\
\hline $\begin{array}{l}\text { Gebeliğe-ilişkin } \\
\text { psikososyal değişiklikler }\end{array}$ & $1.00-5.00$ & $1.33-5.00$ & $3,7 \pm 0,7$ \\
\hline GPSDÖ toplam & $1.00-5.00$ & $2,6-4,9$ & $4 \pm 0,3$ \\
\hline
\end{tabular}




\begin{tabular}{|c|c|c|c|c|c|c|}
\hline \multirow{2}{*}{$\begin{array}{l}\text { Değişken } \\
\text { Yaş ort: } 28,3 \pm 5.4\end{array}$} & \multicolumn{3}{|c|}{$\begin{array}{r}\text { GYYKEÖ } \\
\end{array}$} & \multicolumn{3}{|c|}{ GPSDÖ } \\
\hline & Mean \pm SS & $\mathbf{t} / \mathbf{F}$ & $\mathbf{p}$ & Mean \pm SS & $\mathbf{t} / \mathbf{F}$ & $\mathbf{p}$ \\
\hline \multicolumn{7}{|l|}{ Yaş grubu } \\
\hline $18-34$ & $74,7 \pm 27,4$ & \multirow[b]{2}{*}{$-1,671$} & \multirow[b]{2}{*}{0,096} & $4 \pm 0,3$ & \multirow[b]{2}{*}{0,636} & \multirow[b]{2}{*}{0,444} \\
\hline$\geq 35$ & $81,2 \pm 30,5$ & & & $4 \pm 0,4$ & & \\
\hline \multicolumn{7}{|c|}{ Algılanan Ekonomik Durum } \\
\hline Gelirim giderimden az & $85,3 \pm 35,8$ & \multirow[b]{3}{*}{3,848} & \multirow[b]{3}{*}{$0,022^{*}$} & $3,9 \pm 0,4$ & \multirow[b]{3}{*}{2,534} & \multirow[b]{3}{*}{0,081} \\
\hline Gelirim giderime eşit & $75,4 \pm 26,7$ & & & $4 \pm 0,3$ & & \\
\hline Gelirim giderimden fazla & $70,2 \pm 26,6$ & & & $4,1 \pm 0,3$ & & \\
\hline \multicolumn{7}{|l|}{ Aile tipi } \\
\hline Çekirdek & $74,8 \pm 28,8$ & \multirow[b]{3}{*}{0,275} & \multirow[b]{3}{*}{0,759} & $4 \pm 0,3$ & \multirow[b]{3}{*}{0,135} & \multirow[b]{3}{*}{0,873} \\
\hline Geleneksel & $76,1 \pm 23,6$ & & & $4 \pm 0,3$ & & \\
\hline Parçalanmış & $84,2 \pm 32,2$ & & & $4 \pm 0,3$ & & \\
\hline \multicolumn{7}{|l|}{ Eğitim } \\
\hline Okur-yazar değil & $62,3 \pm 31,6$ & \multirow{6}{*}{2,126} & \multirow{6}{*}{0,062} & $4,2 \pm 0,3$ & \multirow{6}{*}{2,47} & \multirow{6}{*}{$0,032^{*}$} \\
\hline Okur-yazar & $51,8 \pm 33,6$ & & & $3,7 \pm 0,6$ & & \\
\hline İlkokul & $76,1 \pm 24,4$ & & & $4 \pm 0,3$ & & \\
\hline Ortaokul & $77 \pm 24,3$ & & & $4 \pm 0,3$ & & \\
\hline Lise & $73 \pm 28,4$ & & & $4 \pm 0,3$ & & \\
\hline Üniversite ve üstü & $78,8 \pm 30,7$ & & & $4 \pm 0,3$ & & \\
\hline \multicolumn{7}{|l|}{ Çalıșma Durumu } \\
\hline Çalışmıyor & $76,8 \pm 27$ & \multirow[b]{2}{*}{0,603} & \multirow[b]{2}{*}{$0,021^{*}$} & $4 \pm 0,3$ & \multirow[b]{2}{*}{0,512} & \multirow[b]{2}{*}{0,609} \\
\hline Çalışıyor & $68,6 \pm 29,3$ & & & $4 \pm 0,4$ & & \\
\hline Gravida & & & & & & \\
\hline Primigravida & $74,9 \pm 27,4$ & & & $4 \pm 0,3$ & & \\
\hline Multigravida & $75,2 \pm 28,1$ & 0,119 & 0,906 & $4 \pm 0,3$ & 0,245 & 0,807 \\
\hline Gebeliğin planlı olması & & & & & & \\
\hline Evet & $75,5 \pm 27,5$ & & & $4 \pm 0,3$ & & \\
\hline Hayır & $73,4 \pm 29,5$ & 0,546 & 0,585 & $3,9 \pm 0,4$ & 1,948 & 0,052 \\
\hline Yaşayan çocuk & & & & & & \\
\hline Yok & $76,3 \pm 26,7$ & & & $4 \pm 0,3$ & 0,978 & 0,329 \\
\hline Var & $74,3 \pm 28,6$ & 0,687 & 0,493 & $4 \pm 0,3$ & & \\
\hline Trimester & & & & & & \\
\hline 1 & $72,7 \pm 29,1$ & & & $4, \pm 0,3$ & & \\
\hline 2 & $67,7 \pm 35,4$ & 3,937 & $0,020^{*}$ & $4 \pm 0,4$ & 0,35 & 0,906 \\
\hline 3 & $77,7 \pm 24,7$ & & & $4 \pm 0,3$ & & \\
\hline
\end{tabular}

\begin{tabular}{|l|c|c|}
\hline \multicolumn{3}{|l|}{ Tablo 4. Katılımcıların GYYKEÖ ile GPSDÖ puan ortalamaları arasındaki ilişki } \\
\hline \multicolumn{1}{|c|}{ GPSDÖ } & $\mathbf{R}^{\boldsymbol{\beta}}$ & GYYKEÖ \\
\hline Gebelik ve Eş İlişkisi & $\mathrm{r}$ & 0,005 \\
& $\mathrm{p}$ & 0,918 \\
\hline Kaygı ve Stres & $\mathrm{r}$ & $-0,164$ \\
& $\mathrm{p}$ & $\mathbf{0 , 0 0 1 ^ { * }}$ \\
\hline Aile içi şiddet & $\mathrm{r}$ & $-0,037$ \\
& $\mathrm{p}$ & 0.474 \\
\hline Psikososyal Destek Gereksinimi & $\mathrm{r}$ & -0.217 \\
& $\mathrm{p}$ & $\mathbf{0 , 0 0 0 ^ { * }}$ \\
\hline Ailesel özellikler & $\mathrm{r}$ & -0.056 \\
& $\mathrm{p}$ & 0,278 \\
\hline Gebeliğe İlişkin Fiziksel-Psikososyal Değişiklikler & $\mathrm{r}$ & $-0,127$ \\
& $\mathrm{p}$ & $\mathbf{0 , 0 1 3}$ \\
\hline GPSDÖ Toplam & $\mathrm{r}$ & $-0,149$ \\
& $\mathrm{p}$ & $\mathbf{0 , 0 0 4}$ \\
\hline
\end{tabular}

${ }^{\beta}$ Pearson Korelasyon $\quad * \mathrm{p}<0.05$ 


\section{TARTIŞMA}

Gebelikteki yakınmaların, yaşam kalitesine etkisi ile psikososyal sağlık düzeyi arasındaki ilişkinin belirlenmesi amacıyla yapılan araştırmadan elde edilen bulgular ilgili literatür doğrultusunda tartışılmıştır.

Araştırmada, gebelikteki yakınmaların yaşam kalitesine etkisi ile GPSDÖ " "gebelik ve eş ilişkileri", "aile içi şiddet" ve "ailesel özellikler" alt boyutları toplam puan ortalamaları arasında istatistiksel açıdan anlamlı bir ilişki olmadığ saptanmıştır ( $\mathrm{p}>0.05)$. Gebelikte psikososyal sağlığ etkileyen eş ilişkileri, aile içi şiddet ve ailesel özelliklerin gebelik yakınmaları ile ilgili yaşam kalitesi ile ilişkili olmadığı görülmektedir. Buna karşın literatürde, gebe kadınların en önemli destek kaynaklarının yakın aile üyeleri ve özellikle eşleri olduğ ${ }^{16}$ ve gebelik rolü eşi tarafından onaylanan ve sorunlarını eşiyle paylaşabilen gebelerin daha az yakınma yaşadıkları belirtilmektedir. ${ }^{17}$ Elde edilen bulgu, literatürle farklılık göstermekle birlikte araştırmanın yapıldığ 1 ilde gebe kadınlara şiddet uygulanmasının eş ve aileler tarafından hoş görülen bir davranış olarak kabul edilmediği ve eş ilişkileri ve ailesel özelliklerin iyi düzeyde olduğu düşünülebilir. Buna karşın, gebelikteki yakınmaların yaşam kalitesine etkisi ile GPSDÖ "Kaygı ve Stres" ve "Gebeliğe İlişkin FizikselPsikososyal Değişiklikler" alt boyutları puan ortalamaları arasında negatif yönde anlamlı bir ilişki olduğu belirlenmiştir $(\mathrm{p}<0.05)$. Araştırmada, kayg1 ve stres ile gebeliğe ilişkin fizikselpsikososyal değişikliklerin gebelik yakınmaları ile ilgili yaşam kalitesini azalttığı görülmektedir. Qiu ve arkadaşlarının yapmış olduğu çalışmada da kısa süreli uyku problemi yaşayan gebelerde, duygu durum bozukluğu ve algılanan stres düzeyinde artış olduğu saptanmıştır. ${ }^{17}$ Literatürde benzer şekilde, gebelikte meydana gelen fizyolojik, psikososyal değişimlerin ya da olası komplikasyonların anne adayında kaygı ve strese yol açabileceği ve ${ }^{19}$ gebelerin yaşadığı bu kaygının yaşam kalitesini olumsuz yönde etkileyebileceği bildirilmiştir. ${ }^{10}$ Elde edilen bulgunun literatürle uyumlu olduğu görülmektedir.

Araştırmada, gebelikteki yakınmaların yaşam kalitesine etkisi ile GPSDÖ "Psikososyal Destek Gereksinimi" alt boyutu puan ortalaması arasında negatif yönde anlamlı bir ilişki olduğu $(\mathrm{p}<0.05)$ ve psikososyal destek gereksiniminde algılanan yetersizliğin, yakınmalara bağlı yaşam kalitesini olumsuz yönde etkilediği belirlenmiştir. Sosyal desteğin en önemli işlevi, stres verici yaşam olaylarının yarattığı zararları azaltarak ya da dengeleyerek ruh sağlığını korumaktır. ${ }^{20} \mathrm{Bu}$ nedenle, sosyal destek eksikliği olan gebelerin stresleriyle baş etmede güçlük yaşayabilecekleri, artan stres sonucunda da gebeliklerinde fiziksel yakınmalarla daha fazla karşılaştıkları belirtilmektedir. $^{21}$ Sosyal destek sistemi bireyin sosyolojik ve psikolojik sorunlarının çözümü, önlenmesi ve tedavisinde, zorlu durumlarla başa çıkabilmesinde güçlü bir kaynaktır. ${ }^{21}$ Kadının sosyal çevresinden aldığı destek sayesinde, gebeliğinde daha az yakınma yaşadığı ve gebeliği olumlu geçirdiği belirtilmektedir. ${ }^{22}$ Okanlı ve arkadaşlarının yapmış olduğu çalışmada, gebelikte algılanan sosyal desteğin bireyin baş etme becerilerini geliştirdiği saptanmıştır. ${ }^{23} \mathrm{Bu}$ araştırmada, benzer şekilde psikososyal destek gereksiniminin gebelik yakınmalarına bağlı yaşam kalitesiyle ilişkili önemli bir etken olduğu görülmektedir.

Araştırmada, gebelikteki yakınmaların yaşam kalitesine etkisi ile "GPSDÖ Toplam" puan ortalaması arasında negatif yönde anlamlı bir ilişki olduğu ve gebelikteki yakınmaların yaşam kalitesine olan olumsuz etkisi etkisi arttıkça, gebelikte psikososyal sağlık düzeyinin azaldığ belirlenmiştir $(p<0.05)$. Gebelik, fizyolojik, psişik, hormonal ve sosyal değişimlerin yaşandığ dönemdir ve gebelik bir kadının duygusal acılar ve psikiyatrik morbidite riskini artırmaktadır. ${ }^{15,24}$ Temelde gebelikte meydana gelen fizyolojik yakınmalar (bulantı, kusma, yorgunluk duygusallık vb), gebe kadında ciddi olarak yaşam kalitesini bozan bir etkiye sahiptir. ${ }^{7} \mathrm{Bu}$ durum gebeliğin seyrini olumsuz yönde etkileyip, psikososyal sağlık düzeyinin düşük olmasına neden olmaktadır. ${ }^{6} \mathrm{Bu}$ açıdan değerlendirildiğinde elde edilen bulgunun literatürle uyumlu olduğu ve gebelik yakınmalarına bağlı yaşam kalitesinin, psikososyal sağlık düzeyi ile ilişkili önemli bir etken olduğu sonucuna varılmıştır.

$\mathrm{Bu}$ araştırmanın bazı sınırlılıkları bulunmaktadır. İlk sınırlılık, bu araştırmanın Türk gebe kadınlar üzerinde yapılmasıdır. $\mathrm{Bu}$ nedenle, bu araştırma genel popülasyona ve diğer toplumlara genellenemez. Araştırmaya, sadece sağlıklı gebelerin alınması ise bu araştırmanın diğer bir sınırlılığıdır.

\section{SONUC}

Gebelikteki yakınmaların yaşam kalitesine etkisi ile psikososyal sağlık düzeyi arasında ters bir ilişki olduğu, gebelikteki yakınmaların yaşam kalitesine olan olumsuz etkisi arttıkça, psikososyal sağlık düzeyinin de anlamlı düzeyde azaldığ belirlenmiştir. Prenatal sağlık bakım hizmetleri kapsamında, sağlik profesyonelleri tarafindan gebelik yakınmalarının sorgulanması ve gebelik yakınmalarını gidermeye/azaltmaya yönelik planlanacak girişimlerin uygulanması, gebelikteki psikososyal sağlık düzeyinin yönetimine katk1 sağlayacaktır. 
Yazarlar
bulunmamaktadır.

\section{KAYNAKLAR}

1. Karaçam Z, Ançel G. Depression, anxiety and influecing factors in pregnancy: a study in Turkish population. Midwifery 2009;25:34456.

2. Şahin EM, Kılıçarslan S. Son trimester gebelerin depresyon ve kaygı düzeyleri ve bunları etkileyen etmenler. Trakya Univ Tip Fak Derg 2010; 27: 51-8.

3. Arslan B, Arslan A, Kara S, Öngel K, Mungan MT. Gebelik anksiyete ve depresyonunda risk faktörleri: 452 olguda değerlendirme. Tepecik Eğit Hast Derg 2011; 21: 79-84.

4. Mecdi M, Rathfisch G. Gebelikte oluşan rahatsızlıklarda kanıta dayalı uygulamalar. F.N. Hem. Derg 2013; 21: 129-38.

5. Özorhan EY, Ejder AS, Şahin Altun Ö. Gebelikte ruh sağlığı. Yıldırım Beyazıt Üniversitesi Sağlık Bilimleri Fakültesi Hemşirelik E-Dergisi 2014; 2: 33-42.

6. Şahan Ö. Erken gebelik döneminde yaşanan bulantı kusma sıklığı ve bulantı kusmanın yaşam kalitesine etkisi.Yüksek lisans tezi. Konya: Selçuk Üniversitesi, 2012; s. 2.

7. Arabacıŏlu C. Gebelerde yaşam kalitesi ve eğitim gereksinimlerinin belirlenmesi.Yüksek lisans tezi. İstanbul: İstanbul Bilim Üniversitesi; 2012; s. 1.

8. Haakstad A.H.L, Torset B, Kari Bø. What is the effect of regular group exercise on maternal psychological outcomes and common pregnancy complaints? An assessor blinded RCT. Midwifery 2016;32:81-86

9. Çınar Ö, Sürmeli M,Özel A,Yavuz İE,Topçuoğlu A, Ankaralı H. Gebelerde fiziksel aktivite ve yaşam kalitesi arasındaki ilişki. Anadolu Kliniği Tıp Bilimleri Dergisi, 2017; 22(2):95-102.

10. Özçelik G. Gebelikte sık karşılaşılan yakınmalar, fiziksel, ruhsal ve cinsel sağlık sorunları, risk faktörleri ve yaşam kalitesi ile ilişkileri. Ege Üniversitesi Hemşirelik Fakültesi Dergisi 2014; 3:1 -18.

11. Özorhan EY. Gebelikteki yakınmalar ve yaşam kalitesine etkisi ölçeğinin Türkçe geçerlilik ve güvenilirlik çalışması. Sağlı Bilimleri Enstitüsü, Doğum, Kadın Sağlığı ve Hastalıkları Hemşireliği Ana Bilimdalı. Doktora Tezi, Erzurum: Atatürk Üniversitesi 2016; s. 37.
12. Özdamar Ö, Yılmaz O, Beyca HH, Muhcu M. Gebelik ve postpartum dönemde sik görülen ruhsal bozukluklar. Zeynep Kamil Tıp Bülteni 2014; 45:71-7.

13. Körükcü Ö, Deliktaş A, Aydın R, Kabukcuoğlu K. Gebelikte psikososyal sağlık durumu ile doğum korkusu arasındaki ilişkinin incelenmesi. Clin Exp Health Sci 2017; 1-6.

14. Yıldız H. Gebelikte psikososyal sağlığ değerlendirme ölçeği geliştirme çalışması. Maltepe Üniversitesi Hemşirelik Bilim ve Sanatı Dergisi 2011; 4: 63-74.

15. Gümüşdaş M, Ejder AS, Özorhan EY. Riskli olan ve olmayan gebelerin psiko-sosyal sağlıklarının karşılaştırılması. HSP 2014,1: 3242.

16. Yekenkunrul D, Mete S. Gebelikte bulantı kusma, evlilik uyumu ve eş ilişkisi arasındaki ilişkinin incelenmesi. DEUHYO ED 2012; 5: 89-95.

17. Qiu C, Gelaye B, Fida N, Williams MA. Short sleep duration, complaints of vital exhaustion and perceived stress are prevalent among pregnant women with mood and anxiety disorders. BMC Pregnancy and Childbirth 2012; 12: 104-113

18. Karataş T, Gebelikte bulantı kusma ile sosyal destek arasındaki ilişki. Erişim: http://acikerisim.deu.edu.tr/xmlui/bitstream/ha ndle/12345/10056/281943.pdf. Erişim Tarihi:20.03.2018

19. Kılıçarslan S. Edirne şehir merkezindeki son trimester gebelerin sosyodemografik özellikleri, yaşam kaliteleri, kaygı düzeyleri. Uzmanlık tezi. Edirne: Trakya Üniversitesi; 2008; s.1.

20. Ardahan M. Sosyal destek ve hemşirelik. Atatürk Üniversitesi Hemşirelik Yüksekokulu Dergisi 2006; 9:(2) 67-75

21. Paarlberg K.M, Vingerhoets A.J.J.M, Passchier J, et.al. Psychosocial factors as predictors of maternal well-being and pregnancy-related complaints. Journal of Psychosomatic Obstetrics and Gynecology, 1996; 17: 93-102.

22. Mermer G, Bilge A, Yücel U, Çeber E. Gebelik ve doğum sonrası dönemde sosyal destek algısı düzeylerinin incelenmesi Journal of Psychiatric Nursing, 2010; 2: 71-76

23. Okanlı A, Tortumluoğlu G, Kırpınar İ. Gebe kadınların ailelerinden algıladıkları sosyal destek ile problem çözme becerileri arasındaki ilişki. Anadolu Psikiyatri Dergisi 2003; 4:98105

24. Silva MMJ, Nogueira DA, Clapis MJ, Leite EPRC. Anxiety in pregnancy: prevalence and associated factors. Rev Esc Enferm USP. 2017;51:e03253. 